\title{
A Global Ecological Ethic for Human Health Resources
}

\author{
Lisa A. Eckenwiler
}

Received: 11 May 2020 / Accepted: 26 August 2020

(C) Journal of Bioethical Inquiry Pty Ltd. 2020

\begin{abstract}
COVID 19 has highlighted with lethal force the need to re-imagine and re-design the provisioning of human resources for health, starting from the reality of our radical interdependence and concern for global health and justice. Starting from the structured health injustice suffered by migrant workers during the pandemic and its impact on the health of others in both destination and source countries, I argue here for re-structuring the system for educating and distributing care workers around what I call a global ecological ethic. Rather than rely on a system that privileges nationalism, that is unjust, and that sustains and even worsens injustice, including health injustice, and that has profound consequences for global health, a global ecological ethic would have us see health as interdependent and aim at "ethical place-making" across health ecosystems to enable people everywhere to have the capability to be healthy.
\end{abstract}

Keywords Health workers · Human health resources · Globalization $\cdot$ Health justice $\cdot$ Health equity $\cdot$ Care workers · Migrant care workers · Global justice . Structural injustice $\cdot$ Vulnerability

\section{A. Eckenwiler $(\square)$}

George Mason University Department of Philosophy, Fairfax, VA, USA

e-mail: leckenwi@gmu.edu

\section{Introduction}

COVID-19 has highlighted with lethal force the need to re-imagine and re-design the provisioning of human resources for health, starting from the reality of our radical interdependence and concern for global health and justice. Starting from the structured health injustice suffered by migrant workers during the pandemic and its impact on the health of others in both destination and source countries, I argue here for re-structuring the system for educating and distributing care workers around what I call a global ecological ethic. Rather than rely on a system that privileges nationalism, that is unjust, and that sustains and even worsens injustice, including health injustice, and that has profound consequences for global health, a global ecological ethic would have us see health as interdependent and aim at "ethical place-making" across health ecosystems to enable people everywhere to have the capability to be healthy.

\section{Migrant Care Workers and the Interdependence of Global Health}

Foreign-born and educated care workers-doctors, nurses, nurse assistants, and others who have laboured under inequities in many destination countries-have found themselves on the front line of crisis response as the global pandemic of COVID-19 has unfurled, facing 
health risks for themselves and their families. Current evidence shows that BAME (Black, Asian, and Minority Ethnic) doctors working in the United Kingdom's National Health Service have become ill and died in disproportionate numbers (Campbell 2020). Many of these health workers, as migrants, were in the throes of what had been the painful and protracted process of being herded out under Brexit. However, in order to mobilize them in the country's fight against the virus, the government hastily extended their visas. Prime Minister Boris Johnson, indeed, upon emerging from hospital, famously - because ironic — praised nurses "Jenny from New Zealand and Luis from Portugal" (Booth et al., 2020).

The substantial portion of migrants working in longterm care (LTC), a sector especially notorious for poor conditions even in high income countries (HICs), have also stood in harm's way as the pandemic gripped nursing homes and other LTC settings (Bachega 2020; Cenziper et al. 2020; McGreal 2020). These care workers, mostly women and many of them long-term residents or even citizens in destination countries, have withstood injustice as migrants (Eckenwiler 2012). Those for whom employment in a destination country may literally be a lifeline are especially vulnerable. Haitian asylum seekers in Quebec offer an illuminating example (Stevenson and Shingler 2020a, 2020b). As they await decisions on their applications for admission, they have access only to temporary, part-time workemployment they need urgently for the sake of survival and which they hope will strengthen their cases. Many hold multiple jobs in LTC, one of the few available options, traveling from care setting to care setting. When the pandemic arrived, this relationship between immigration policies, health policies, and labour policies, combined with the related reluctance to raise concerns about inadequate staffing, information, and protective equipment for fear of sanction (discrimination, job loss, rejection of visas, asylum claims, and deportation) heightened the risk of exposure, illness, and death for them and their families (Villareal 2020). These socially constructed health vulnerabilities proved, in turn, to pose a major threat to the elderly and disabled people for whom they cared and to public health.

In other HICs, migrants were recruited for work when COVID-19 began overwhelming healthcare systems. These migrants previously had long waits for recognition of their credentials and in some cases been rejected, even in countries with longstanding shortages of health workers. Other asylum seekers and refugees like displaced Syrian doctors who had struggled to have their qualifications recognized were quickly licenced and integrated into German healthcare settings, even serving in places like Saxony where anti-immigrant sentiment looms large (Alkousa and Carrel 2020; Connolly 2020). Similar experiences happened in France, where Algerian doctors and more recent refugees have been asked to join the health work force (Bryant 2020) and in Chile where Venezuelans, previously excluded from the ranks of recognized health professionals, have been put to work in some of the country's largest and poorest hospitals (Laing 2020). And in Italy, health workers from China, Cuba, and Albania were brought in to support the country in combatting the pandemic without having to navigate the usual immigration and credentialing barriers (Dempster and Smith 2020). Considered in combination, these stories show that in combatting COVID-19, HICs were already reliant on migrant care workers, were eager to retain them when crisis hit, to grant status recognition to others waiting, and to welcome new migrants across borders under rapid immigration and healthcare licencing policy reforms (ODI 2020).

A complex configuration of transnational structures, including economic, health, labour, and immigration policies, have long generated injustice against migrant care workers, especially those from low- and middleincome countries (LMICs) despite the vital role they play in health and long-term care systems around the world. In earlier work I argued that these structures serve to erode autonomy and equality for these workers and threaten their capability to be healthy $(\mathrm{CH})$. They also undermine the $\mathrm{CH}$ of their family members. Furthermore, the injustice suffered by these care workers constrains the $\mathrm{CH}$ of the vulnerable people they care for, their family members, and that of the populations of their source countries who are also confronting aging, high disease burdens, and an increased possibility of epidemics, yet with less in the way of resources (Eckenwiler 2012). We should see these individuals and groups, their social and material environs, and crucially, their $\mathrm{CH}$, as interdependent. All are subjects of unique lives, yet all are situated in social and material environs that reflect and perpetuate structural injustice.

As Young explains it, structural injustice "exists when social processes put large categories of persons under a systematic threat of domination or deprivation of the means to develop and exercise their capacities, at 
the same time as these processes enable others to dominate or have a wider range of opportunities for developing and exercising their capacities" $(2011,52)$. Structured health vulnerabilities and injustice, in turn, involve: an "increased propensity to incur health risks directly related to social inequalities stemming from structural and epistemic injustices that affect an individual or a social group" (Chung et al., Forthcoming).

The global pandemic of COVID 19 has laid bare the injustice-which should be understood as structural injustice - that continues to be suffered by these same groups and its implications for their $\mathrm{CH}$. The pandemic has, moreover, made it even more abundantly clear that what might seem to be dispersed individuals and populations of people around the world are in fact connected. The health of a farmer in a small village in China is connected to and interwoven with that of a banker in New York City. Doctors and nurses anywhere are indispensable to the lives of the ill and frail everywhere. Where they are living in precarity and/or under discriminatory policies, the health of everyone suffers.

To capture our radically relational embeddedness and interdependence when it comes to health and health justice in a context of globalization, I have argued for the necessity of conceiving of people as "ecological subjects": corporeal forms of life situated in (often unjust) social structures and also embedded in particular atmospheric and material contexts - habitats or places of dwelling - that must meet certain conditions to sustain life. Thinking of people as ecological subjects situated in health ecosystems (which intersect with others) helps to properly capture the scope of the claim for health justice by directing attention to the places in which people dwell and through which we navigate (like LTC and other under-resourced settings in HICs, hospitals in LICs, borders and other sites of migration processing, workplaces, homes, urban neighborhoods), and more precisely, what structures and processes contribute to the creation of the conditions that threaten health justice there. An ecological conception of subjects also illuminates the intersubjectivity of health or the idea that we are constitutive of one another and our $\mathrm{CH}$ for we "dwell together" in "complex, causal" relations of interdependence (Young 2000, 224). We contribute to the construction of one another's health through our actions and interactions, which are embedded and situated within a global context of social structures and processes including policy choices and also inaction. These structures serve to enable some people in the realization of their capacities yet constrain others, creating and/or sustaining injustice.

The processes for educating and deploying health workers are a vital component of the global apparatus that creates and sustains health vulnerabilities and shapes the potential of ecological subjects to realize the $\mathrm{CH}$. The movement of "human health resources" around the world - a decades-old phenomenon-has been accelerating for some time. The number of migrant doctors and nurses, typically from low- and middleincome countries, working within OECD countries increased by 60 per cent over the last decade (Carzaniga et al. 2019), even as they've faced increasingly hostile immigration and social policies. Although a thorough description is not possible here, the global structure involving the "perverse subsidy" of LMICs educating and either exporting intentionally or unable to stem the outward flow of their health workers toward HIC jobs (often with the consequence of "de-skilling" or working below the level of their training and education) has been well documented. Now, given the scale of global displacement, a growing number are migrating on their own-fleeing life-threatening situations and willing to work in precarious conditions and often in positions poorly matched to their abilities.

\section{From National Self-Sufficiency to a Global Ecological Ethic: A Sketch}

Strategizing for human health resources proceeds from the perspective of a presumptive nationalism as governments (in most cases) aspire toward protecting the health of their own citizens. Even, indeed, as it calls for a "paradigm shift" in how we plan for, finance, education, distribute, and properly support health workers, the WHO $(2016,12)$ calls for national self-sufficiency and overall, assumes a framework of nationalism in its Global Strategy on Human Resources for Health: Workforce 2030. This attempt at envisioning innovation within the same overall structure for educating and distributing human resources for health, however, seems ill fated to achieve its stated goal of "ensuring equitable access to HRH" and address the motivating concerns of underproduction, maldistribution, mismatch between need and education and, of course, maltreatment of migrants under unjust immigration and labour policies. 
The present system that privileges nationalism is unjust and what's worse, sustains and deepens injustice, has potentially lethal consequences for global health. I propose a re-structuring around a global ecological ethic. On a global ecological ethic, people are conceived as ecological subjects and health as interdependent. The notion of health as a global public good (GPG) helps to capture this. This idea holds, first, that if health is not protected current and future people will be exposed to significant preventable harm and second, that health requires collective action between individuals and countries for protection (Kaul and Faust 2001; Widdows and Marway 2015). Once these goods are provided no one is excluded from accessing them and one person's use does not threaten others'. Richard Smith $(2003,475)$ offers the example of reduction in risk of infectious disease from which,

... no one in a population can be excluded ... and one person benefiting from this reduction in risk does not prevent anyone else from benefiting from it as well ... Similarly, the eradication of infectious diseases of global scope, such as smallpox or polio, provides a benefit from which no country is excluded, and from which all countries will benefit without detriment to others.

As he and others have noted, GPG as a concept has its liabilities (the discussion of which goes beyond my scope here); yet it also has potential for motivating the provisioning of global health efforts.

I suggest conceiving of health workers as GPGs, unbound by borders, or as "de-territorialized" resources for health (Chung et al., 2020). If they are not protected, people will (continue to) face serious harm. Indeed, the WHO's Strategy document describes them as "enablers." Their protection requires collective action. Finally, they are non-excludable and non-rivalrous. The particular collective effort I want to propose here is the establishment of a Global Fund for Human Health Resources (GFHHR) (Gostin 2014). Such a fund would support the education, training, and equitable distribution of cadres of health workers with expertise in responding to health needs in particular health "ecosystems." These might be construed in a variety of ways - according to promotive, preventive, curative, chronic management, and palliative care; by life stage, form of illness or disability, or other - and in all instances conceived as situated or implaced in a range of social and cultural settings and atmospheric-geographic locations.

The aim on a global ecological ethic is what I have theorized as the ideal and practice of "ethical placemaking" (EPM), an essential element of health justice that demands attention to place and its impact on health. EPM calls for, among other things: nurturing of care relations; protection of bodily integrity; and equity (Eckenwiler 2016, 2018). A fair distribution of health and other care workers with fitting expertise who can operate unconstrained by ever-fluctuating border regimes upholds each of these.

The mapping and identification of needs within particular health ecosystems should be conducted according to principles of epistemic justice (Fricker 2007), privileging the perspectives of the ecological subjects who dwell there-caregivers and those in need of care - in a manner akin to what others have described as "bio regional narratives" (Cheney 1989). This helps promote equity across ecosystems as well as respect for autonomy, a fourth element of EPM. EPM also calls for supporting ecological subjects in feeling rooted but also having abilities for generative movement. This means people should suffer neither stagnation nor hypermobility nor movement across borders or other terrain under duress. By de-territorializing human health resources and making them GPGs, coordinated and allocated at a global level, a global ecological ethic can remove the burden posed by borders and immigration regimes on health workers and the $\mathrm{CH}$.

Taking a position on whether a prioritarian, sufficientarian, egalitarian, or some other distribution scheme in deploying health workers is best is not possible here given space constraints. Many additional questions remain concerning, for example: what kinds of HRHs warrant the most investment given their mix of skills and scope of practice; how to conceive of and map health ecosystems; how to conduct an epistemically just mapping; how to ensure care worker autonomy and equitable treatment; and how to assign responsibility for investment in such a fund. I leave these questions for future work.

\section{Solidarity and Prudence: Overlapping Justifications}

While we might point to several justifications for supporting and investing in a GFHHRs, here I will focus only on solidarity. The definition of solidarity I follow 
here involves reaching out through engaging our moral imaginations across social and/or geographic distance and asymmetry to recognize and assist others with whom we share something, like vulnerability to illness (Prainsack and Buyx 2017). Solidarity involves two enacted commitments: first to engaging our moral imaginations and recognizing others in need or what I will describe below as "solidaristic recognition"; second, to responsive action or labour in the service of justice.

As I have argued elsewhere, recognizing the suffering of others implaced in conditions unable to sustain them follows from the most minimal appreciation of people as ecological subjects (Eckenwiler 2018). If we conceive of people in ecological terms, appreciation of everyone's equal moral worth ought to take account of the significance of place for the equitable flourishing. We are equal in part because we all share a need to be "in place" in settings that can sustain us and support our capacities. If we also accept the argument above that we are constitutive of one another, our environs, and our health, and contribute to social structures and processes that support some in realizing the capability to be healthy and thwart others, responsibilities for solidaristic action become stronger still, and in turn, responsibilities for health justice in places we have helped to make fragile (Eckenwiler, Chung, and Straehle 2012).

As a final point, when health is seen as a GPG, the prudential motive of interest in often cited as a grounding for collective action. Some see it as a possible segue to solidarity and global justice for those not motivated toward collective action for health (West-Oram, 2017). Either way, globally coordinated, epistemically just efforts toward ensuring more ethical treatment and distribution of HRHs seems better suited to generate health justice, or the $\mathrm{CH}$, around the world than the present system.

\section{References}

Alkousa, R., and P. Carrel. 2020. Refugees to the rescue: Germany taps migrant medics to battle virus. Reuters. March 25. https://www.reuters.com/article/us-health-coronavirusgermany-refugees/refugees-to-the-rescue-germany-tapsmigrant-medics-to-battle-virus-idUSKBN21C2IG. Accessed May 11, 2020.

Bachega, H. 2020. Coronavirus: Inside story of Spain's care home tragedy. BBC News, April 30. https://www.bbc. com/news/world-europe-52188820. Accessed May 8, 2020.

Booth, W., K. Adam, and C. Spoler. 2020. Boris Johnson praises immigrant nurses who saved his life, as Britian's NHS becomes a rallying cry. Washington Post, April 13. https:/www.washingtonpost.com/world/europe/borisjohnson-nurses-nhs/2020/04/13/51498d34-7bfa-11 ea-a311adb1344719a9_story.html. Accessed 10 July, 2020.

Bryant, L. 2020. For foreigners on France's front line, Covid-19 exposes health care shortcomings. VOA News, April 29. https://www.voanews.com/covid-19-pandemic/foreignersfrances-front-line-covid-19-exposes-health-careshortcomings. Accessed May 6, 2020.

Campbell D. 2020. NHS looks into taking BAME staff off frontline for their safety. The Guardian, April 29.

Carzaniga, A., I. Dhillon, J. Magdeleine, and L. Xu. 2019. WTO International health worker mobility and trade in services. WHO-WTO joint staff working paper. Working Paper ERSD-2019-13. https://www.wto.org/english/res_e/reser_ e/ersd201913 e.pdf. Accessed May 1, 2020.

Cenziper, D., J. Jacobs, and S. Mulcahy. 2020. Nearly 1 in 10 nursing homes nationwide report coronavirus cases. Washington Post, April 20. https://www.washingtonpost. com/business/2020/04/20/nearly-one-10-nursing-homesnationwide-report-coronavirus-outbreaks/. Accessed May 9, 2020.

Cheney, J. 1989. Postmodern environmental ethics: Ethics as bioregional narrative. Environmental Ethics 11(2): 117-134.

Chung, R., L. Eckenwiler, and M. Hunt. 2020. De-territorializing the right to health. Paper presented at Resisting borders: Refugee health and responsibilities II. June 18, 2020.

Chung, R., L. Eckenwiler, and M. Hunt. Forthcoming. Health inequalities, structural and epistemic injustices: Structural health vulnerability. Journal of Social Philosophy.

Connolly, K. 2020. Germany calls on migrant medics to help tackle coronavirus. The Guardian, April 14. https://www. theguardian.com/world/2020/apr/14/germany-calls-onmigrant-medics-to-help-tackle-coronavirus? $\mathrm{CMP}=$ share btn_link. Accessed May 10, 2020.

Dempster, H., and R. Smith. 2020. Migrant health workers are on the COVID 19 frontline. We need more of them. Center for Global Development (Blogpost). April 2. https://www. cgdev.org/blog/migrant-health-workers-are-covid-19frontline-we-need-more-them. Accessed May 1, 2020.

Eckenwiler, L. 2018. Displacement and solidarity: An ethic of place-making. Bioethics 32(November): 562-568.

Eckenwiler, L. 2016. Defining ethical place-making for placebased interventions. American Journal of Public Health 106(November): 1944-1946.

Eckenwiler, L. 2012. Long-term care, globalization, and justice. Baltimore: Johns Hopkins University Press.

Eckenwiler, L., R. Chung, and C. Straehle. 2012. Global solidarity, migration, and global health inequities. Bioethics 26(September): 382-390.

Fricker, M. 2007. Epistemic justice: Power and the ethics of knowing. Oxford: Oxford University Press.

Gostin, L. 2014. Ebola: Towards an international health systems fund. Lancet 384(9951): e49-51.

Kaul, I., and M. Faust. 2001. Global public goods and health: Taking the agenda forward. Bulletin of the World Health Organization 79: 869-874.

Laing, A. 2020. Chile's migrant medics move to frontlines in pandemic battle. KFGO 3 July. https://kfgo.com/2020/07 /03/chiles-migrant-medics-move-to-frontlines-in-pandemicbattle/. Accessed June 30, 2020. 
McGreal, C. 2020. "We're living in fear": Why U.S. nursing homes became incubators for the coronavirus. The Guardian, April 15. https://www.theguardian. com/world/2020/apr/15/were-living-in-fear-why-us-nursinghomes-became-incubators-for-the-coronavirus. Accessed May 4, 2020.

Overseas Development Institute (ODI). 2020. Key workers: Migrants' contributions to the Covid 19 response. https://www.odi.org/migrant-key-workers-covid-19/?utm campaign=1394176_ODI\%20newsletter\%201\%20 May\&utm_medium $=$ email\&utm_source $=$ Overseas $\% 20$ Development $\% 20$ Institute\&utm_country $=\& d m \_i=4 \mathrm{O} 2$ W,TVR4,3CDBDZ,3MHTY,1

Prainsack, B., and A. Buyx. 2017. Solidarity in biomedicine and beyond. Cambridge: Cambridge University Press.

Smith, R.D. 2003. Global public goods and health. Bulletin of the World Health Organization 81(7): 475.

Stevenson, V., and B. Shingler. 2020a. Quebec relies on hundreds of asylum-seekers in ling-term care battle against COVID-19. $C B C$, May 8. https://www.cbc. $\mathrm{ca} /$ news/canada/montreal/quebec-chsld-asylum-seekers1.5559354. Accessed June 20, 2020.

Stevenson, V., and B. Shingler. 2020b. How the COVID-19 crisis in Quebec's nursing homes unfolded. $C B C$, April 25. https://www.cbc.ca/news/canada/montreal/timeline-quebecnursing-homes-covid-crisis-1.5544538. Accessed May 9, 2020.

Villareal, A. 2020. Scared and sick amid Covid-19: U.S. nursing home workers afraid to blow the whistle. The Guardian, May 5. https://www.theguardian.com/world/2020/may/05 /us-nursing-homes-coronavirus-outbreak. Accessed May 7, 2020.

West-Oram, P. 2017. Global health solidarity. Public Health Ethics 10(2): 212-224.

Widdows, H., and H. Marway. 2015. A global public goods approach to the health of migrants. Public Health Ethics 8(2): 121-129.

World Health Organization. 2016. Global strategy on human resources for health: Workforce 2030. Geneva: WHO.

Young, I.M. 2000. Inclusion and democracy. Oxford: Oxford University Press.

Publisher's note Springer Nature remains neutral with regard to jurisdictional claims in published maps and institutional affiliations. 